\title{
Prediction of Irrigation Security of Reclaimed Water Storage in Winter Based on ANN
}

\author{
Jinfeng Deng \\ Environmental Science and Engineering College, Huangshi Institute of Technology, \\ Huangshi, P.R China
}

\begin{abstract}
The difference of reclaimed water qualities between in summer and in winter were proved considerable. Reclaimed water derived in spring or summer could be applied irrigating in some arid region, which have been considered a rational renewable resource of water. Yet in winter, reclaimed water would run off into river or stream in vain. The idea of storing it in winter and being ready for the next year's irrigation is proposed, however, the effects on crops are maintained sealed. Experiments processed using raw sewage, primary treated water, and secondary treated water in Gaobeidian Sewage Plant of Beijing to irrigate maize and soybean in spring and summer from 2006 to 2007, based on which the irrigation effect derived from reclaimed water of winter was predicted by ANN. The results validated the strong relations between irrigation effect and qualities of water, which indicated the reclaimed water stored in winter was grossly similar to secondary treated water in summer for irrigation.
\end{abstract}

Keywords: Reclaimed water, storage, irrigation security, ANN.

\section{Introduction}

Reclaimed water derived from industrial and domestic effluents make the role of water resource in some area where the climate is rather dry and irrigation agriculture is the main trend. Quality of reclaimed water may be various based on the effluent quality and treat method, which result in the different usage mode such as industrial recovered water, scenic environmental water, agricultural irrigation water, domestic water, until drinking water. Standardization Administration of the People's Republic of China (SAC) has established serial standards for reclaimed water using and the Standard of Reuse of Urban Recycling Water Quality of Farmland Irrigation Water have been establishing. As the condition of drinking water we concern to, we could not detect all of the parameters involved in water quality but only some parameters. Domestic sewage derived from house holding, commerce, school, hospital, and so on, could include washing water, toilet-flushing water, and the others. A serial standards and rules with regard to medical waste have been established since 2003 in China, so the waste volume from hospital descent to little. However, medical waste should be monitored strictly in the collecting and treating process. Industrial sewage composes of production sewage and production wastewater, the former is the water polluted by 
production raw material and intermediate products and the latter is the one which may not be polluted directly in production process but only be changed the temperature or some physical characteristics, for example cooling water. Generally speaking, the production sewage is the major source of pollution, which may contain some heavy metals, toxicity, acid or alkali materials. On the other hand, the production wastewater and domestic waster could be the main reclaimed water source for recycling use.

In Beijing, the treatment plant received little by little industrial sewage along with the sequent moving of polluting enterprises, and the ratio of effluent volume of domestic sewage to the sum is rather large in China. In 2005 the volume of domestic sewage reaches $8.82 \times 10^{8} \mathrm{t}$, simultaneously the total effluent is $10.10 \times 10^{8} \mathrm{t}$.

Irrigation with reclaimed water is a simple, low-cost, user-friendly way to help conserve our fresh drinking water supplies. In China, the volume of agricultural irrigation water dominates the consumption of water of total quantity, i.e. over $65 \%$. But the water resource of China is not sufficient Per capita quantity of water resource is only $2300 \mathrm{~m}^{3}$, about one forth of ones in the world, while China is the biggest nation of irrigation. Numerous studies indicate that long-term poor quality water irrigation could cause the farm soil and ground water damaged. According to a recent survey to twenty poor quality water irrigation districts, most districts' ground water has been polluted apart from 4 ones. Previous studies indicated that the water quality is the major factor that causes the soil and ground water pollution. Reclaimed water effects the environment by polluting air, soil, ground water and damaging crop. Reclaimed water effecting the environment and crop subject to the season in arid area for water qualities in different season could be various at some levels. Generally speaking, during winter season the concentration of salt, nutrients, heavy metal, and so on, could be higher than during summer season, which cause the different affection on the environment or irrigation security in different seasons. On the other hand, in winter season the reclaimed water could not be used in irrigation but disposal to the environment, while in summer the quantity of reclaimed water could be insufficient for irrigation in arid area. Reclaimed water of winter season often has been discharging into rivers in vain. Could it be use for irrigation in summer via proper storage way of winter season with safety? To solve the problem, we might irrigate crop with reclaimed water stored in winter season but this is a rigescent way which is not able to dispose some different quality reclaimed water else. Artificial Neural Net (ANN) could be a feasible way to predict the affection and security of irrigating crop with stored reclaimed water of winter season.

\section{Materials and Methods}

How would irrigation water of specific quality effect the environment or crop's growth? The experiments by using the specific quality water to irrigate the crop in growth season, which may solve the previous problem but it is noneffective to the various qualities water else. Prediction with ANN may be a feasible utility to definite the irrigation effect using each kind water including reclaimed water. Assuming we meet the same cultural condition such as climate, rainfall quantity, soil, irrigation mode, and so on, then we can decide the different quality irrigation water result in the different 
irrigation effect. This is a black box problem for the reason of mechanism is black to us. To get to know the irrigation effect and security of specific quality water such as reclaimed water from treatment plant in winter, some water which quality is well known would be using as the irrigation water. This study designed potted planting and field experiment and trained the ANN system using several kinds of reclaimed water of raw sewage, secondary reclaimed water, third level reclaimed water and fresh water. ANN demand large amounts of data to train the net, otherwise it would be inadequately trained and result into inaccurate conclusion. Cubic spline interpolation was used to extend the amount of data.

The irrigation water was raw sewage, secondary reclaimed water, third level reclaimed water and fresh water, which respectively derived from Gaobeidian Treatment Plant of Beijing and tap water. Potted plant soil was mixed soil with ground surface 0-80cm from Tongzhou district of Beijing. Planted seeds of maize and soybean were bought from Crop Research Institute of Chinese Agriculture Academy of Science (CAAS). The experiment of potted planting and field experiment has processed respectively in Gaobeidian Treatment Plant and in Institute of Agricultural Environment and Sustainable Development of CAAS. Here are the qualities indices of irrigation water and ones for prediction of specific quality water in these experiments (Table 1).

As shown in Table 1, extension of sample data, normalization of data, training of neural network, and prediction should be completed in a program. In this study back propagation (BP) network has been used to archive these processes. Training function adopted variable learning rate back propagation, VLBP, illustrated with parameter traingdx in Matlab R2006b. A complete process illustrated the previous function as follows (Table2).

Table 1. Quality indices of irrigation water $/ \mathrm{mg} \cdot \mathrm{L}^{-1}$

\begin{tabular}{cccccc}
\hline Component & $\begin{array}{c}\text { Raw } \\
\text { sewage }\end{array}$ & $\begin{array}{c}\text { Secondary } \\
\text { reclaimed } \\
\text { water }\end{array}$ & $\begin{array}{c}\text { Third } \\
\text { level } \\
\text { reclaimed } \\
\text { water }\end{array}$ & $\begin{array}{c}\text { Fresh } \\
\text { water }\end{array}$ & $\begin{array}{c}\text { Irrigation } \\
\text { Water for } \\
\text { prediction }\end{array}$ \\
\hline $\mathrm{BOD}_{5}$ & 187 & 9.25 & 5.85 & 0.94 & 10.10 \\
$\mathrm{COD}_{\mathrm{cr}}$ & 360 & 38.10 & 23.8 & 0.94 & 42.60 \\
$\mathrm{SS}$ & 312 & 12.20 & 5.55 & 4.00 & 12.80 \\
$\mathrm{TN}$ & 43.40 & 30.10 & 20.05 & 7.81 & 33.60 \\
$\mathrm{TP}$ & 4.97 & 1.95 & 2.02 & 0.02 & 3.60 \\
$\mathrm{Cl} 1^{-}$ & 167 & 133 & 143 & 45.9 & 167 \\
$\mathrm{~Pb}$ & 0.28 & 0.31 & 0 & 0 & 0.31 \\
$\mathrm{Cd}$ & 0.02 & 0.01 & 0 & 0 & 0.01 \\
$\mathrm{Zn}$ & 0.24 & 0.13 & 0.05 & 0.02 & 0.13 \\
$\mathrm{EC} / \mu \mathrm{S} \cdot \mathrm{cm}^{-1}$ & 1497 & 1199 & 1184 & 491 & 1199 \\
\hline
\end{tabular}


Table 2. Matlab (R2006b) procedure of artificial neural network

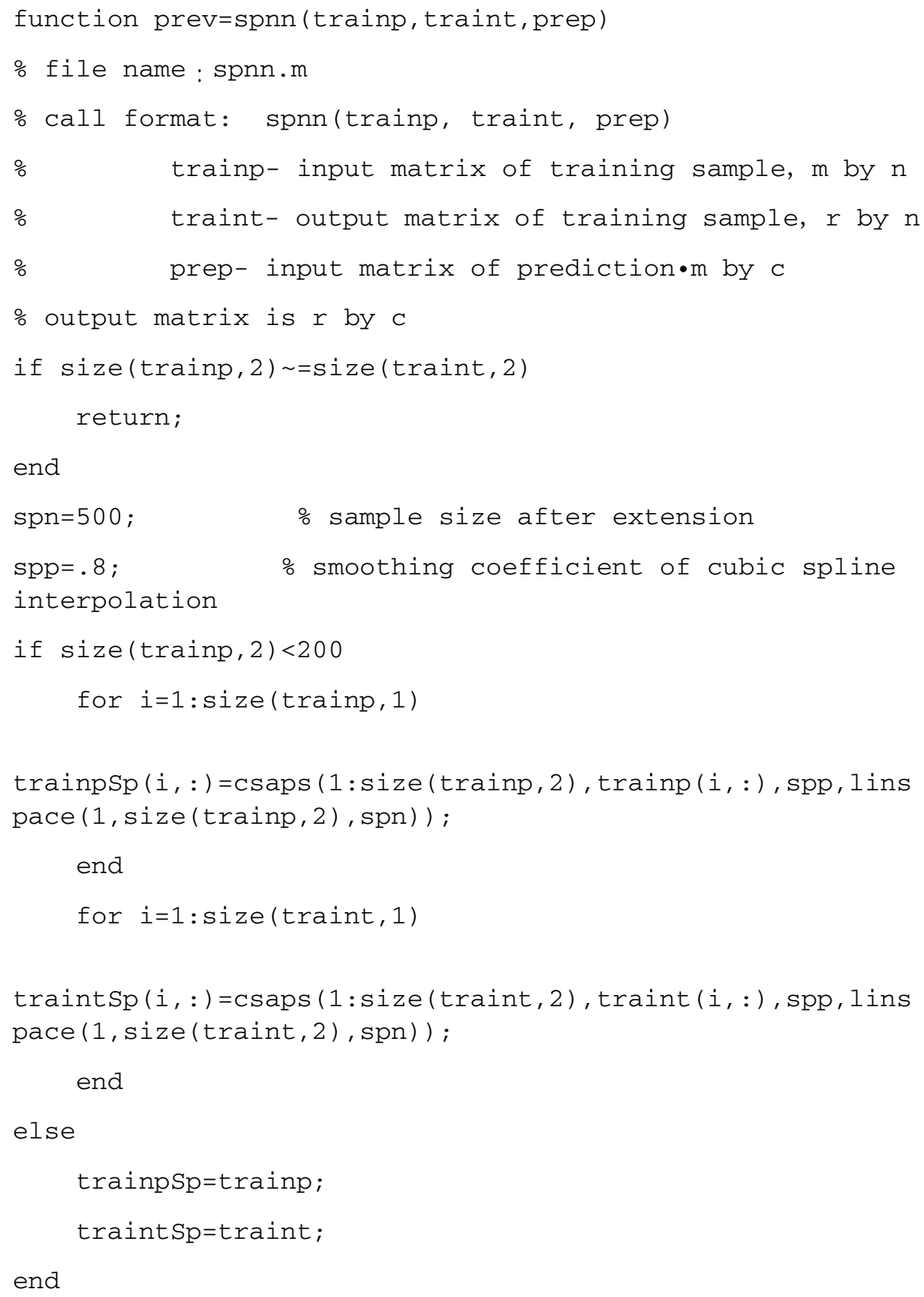


Table 2. (continued)

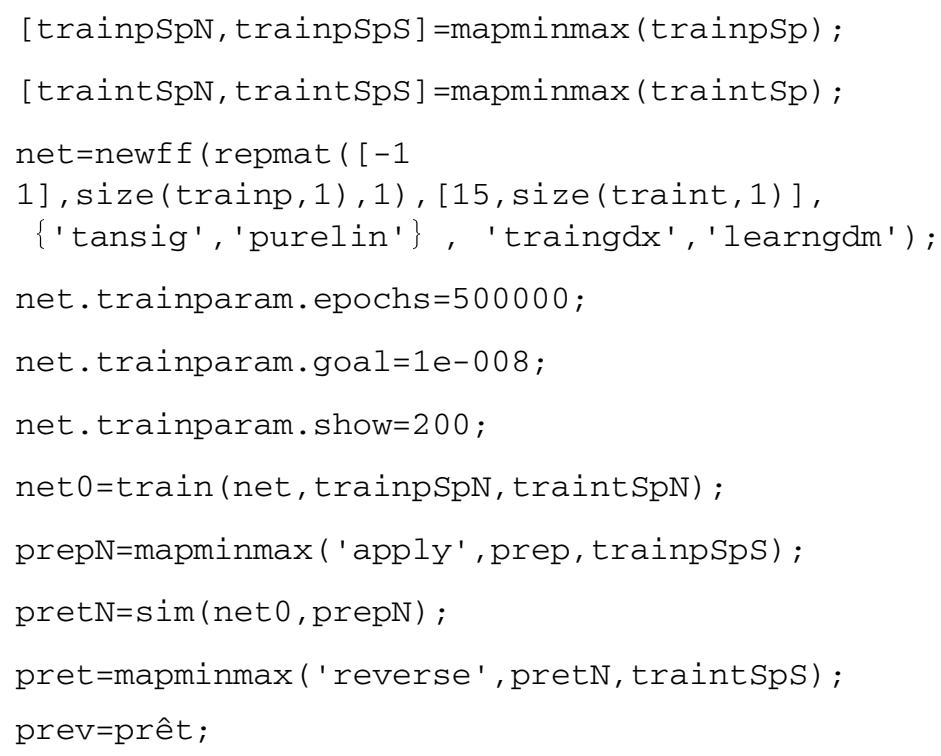

\section{Results and Discussions}

Serial results have been obtained about potted planting and field experiment from experiences in 2005. Before prediction on specific quality irrigation water, the network has been validated with indices of dry weight, plant height, mean grain weight, water using efficiency and it showed the network is efficient. Then the results could be made as follows (only partial prediction result was provided).

Table 3. The content of total C\&N in potted maize's root, stalk and leaves

\begin{tabular}{ccccccc}
\hline \multirow{2}{*}{ treatment } & \multicolumn{2}{c}{ root } & \multicolumn{2}{c}{ stalk } & \multicolumn{2}{c}{ leaves } \\
\cline { 2 - 7 } & $\begin{array}{c}\text { Total } \\
\mathrm{C}(\%)\end{array}$ & $\begin{array}{c}\text { total } \mathrm{N} \\
(\mathrm{mg} / \mathrm{g})\end{array}$ & $\begin{array}{c}\text { total } \\
\mathrm{C}(\%)\end{array}$ & $\begin{array}{c}\text { total } \mathrm{N} \\
(\mathrm{mg} / \mathrm{g})\end{array}$ & $\begin{array}{c}\text { total } \\
\mathrm{C}(\%)\end{array}$ & $\begin{array}{c}\text { total } \mathrm{N} \\
(\mathrm{mg} / \mathrm{g})\end{array}$ \\
\hline Raw sewage & $34.49 \mathrm{ab}$ & 10.90 & $51.78 \mathrm{c}$ & $10.03 \mathrm{~b}$ & $37.54 \mathrm{a}$ & $17.87 \mathrm{~b}$ \\
$\mathrm{~S}$ & $40.34 \mathrm{ab}$ & 8.55 & $41.20 \mathrm{~b}$ & $6.68 \mathrm{a}$ & $44.77 \mathrm{~b}$ & $15.40 \mathrm{ab}$ \\
$\mathrm{T}$ & $31.53 \mathrm{~b}$ & 8.53 & $41.69 \mathrm{~b}$ & $9.00 \mathrm{~b}$ & $40.12 \mathrm{c}$ & $15.47 \mathrm{ab}$ \\
$\mathrm{F}$ & $43.40 \mathrm{a}$ & 7.90 & $30.81 \mathrm{a}$ & $6.63 \mathrm{a}$ & $36.31 \mathrm{a}$ & $11.95 \mathrm{a}$ \\
prediction & 36.49 & 9.42 & 39.70 & 7.35 & 40.55 & 18.54 \\
\hline
\end{tabular}

The different letters represent significant difference in same column.

(1) distribution of component of $\mathrm{C}, \mathrm{N}$ in potted maize

$\mathrm{C}$ in plant is the result of photosynthesis, which indicate the plant growth condition and could be the quality standard as animal feed. $\mathrm{N}$ in plant performs an important 
function during the plant growth and indicates the absorption of plant nutrition. The prediction of effect irrigated by specific water (Table 3 ) shows $\mathrm{C}$ and $\mathrm{N}$ content in the plant root and stack would be close to the one by secondary treated water but the leaves not. It shows the specific water would accelerate the plant growth because the nutrient level is rather high and prior to the secondary treated water.

Table 4. Content of lead and cadmium in pot cultured maize's root, stalk and leaves $/ \mathrm{mg} \cdot \mathrm{kg}^{-1}$

\begin{tabular}{ccccccc}
\hline \multirow{2}{*}{ treatments } & \multicolumn{2}{c}{ roots } & \multicolumn{2}{c}{ stalks } & \multicolumn{2}{c}{ Leaves } \\
\cline { 2 - 7 } & $\mathrm{Pb}$ & $\mathrm{Cd}$ & $\mathrm{Pb}$ & $\mathrm{Cd}$ & $\mathrm{Pb}$ & $\mathrm{Cd}$ \\
\hline Raw sewage & $3.11 \mathrm{c}$ & 0.22 & 1.29 & $0.04 \mathrm{a}$ & 1.87 & 0.03 \\
$\mathrm{~S}$ & $2.66 \mathrm{ab}$ & 0.19 & 1.67 & $0.07 \mathrm{~b}$ & 1.83 & 0.05 \\
$\mathrm{~T}$ & $3.13 \mathrm{bc}$ & 0.19 & 1.41 & $0.04 \mathrm{a}$ & 1.90 & 0.04 \\
$\mathrm{~F}$ & $2.29 \mathrm{a}$ & 0.16 & 1.53 & $0.04 \mathrm{a}$ & 1.78 & 0.03 \\
prediction & 2.85 & 0.20 & 1.54 & $0.06 \mathrm{~b}$ & 1.83 & 0.04 \\
\hline
\end{tabular}

The different letters represent significant difference in same column.

(2) content of some heavy metals in potted maize's root, stalk and leaves

Table 4 shows the content of lead and cadmium in different parts in the potted maize irrigated by four kinds of water and the ones of prediction with the specific water. Content of prediction is rather high and close to the secondary treated water and the content in root is similar to the one of raw sewage. The content of heavy metal in plant is not the simply linear to the one in irrigation water but correlates to the nutrient level.

\section{Conclusions}

The content of $\mathrm{C}$ and $\mathrm{N}$ in root and stack approximates to the secondary treated water of experiment, but it is not the same condition in plant leaves, the content of $\mathrm{C}$ is close to that in third reclaimed water and total $\mathrm{N}$ is largest in all levels, which indicates the special water is in favor of absorbing nutrient and photosynthesis and with more nutritive value for animal feed.

The content of $\mathrm{Pb}$ in plant approximate to secondary reclaimed water in experiment and is between secondary reclaimed water and sewage, which is quite large. Content of $\mathrm{Pb}$ in stack $\left(1.54 \mathrm{mg} \cdot \mathrm{kg}^{-1}\right)$ is close to the level using flesh water in experiment. $\mathrm{Cd}$ is largest irrigated by sewage and third, secondary and flesh water in turn, prediction value is close to third reclaimed water in root and largest in leaves and stack using secondary one. So it is essential to attention the content of $\mathrm{Cd}$ and $\mathrm{Pb}$ in stacks and leaves.

\section{Acknowledgement}

This research was financially supported by Educational Commission of Hubei Province of China (D20104403). 


\section{References}

[1] Chin, K.K.: Pretreatment to produce ultrapure water from reclaimed sewage. Desalination 106, 269-272 (1996)

[2] Al-Shammiri, M., Al-Saffar, A., Bohamad, S.: Waste water quality and reuse in irrigation in Kuwait using microfiltration technology in treatment. Desalination 185, 213-225 (2005)

[3] Verdonck, F.A.M., Boeije, G.: A rule-based screening environmental risk assessment tool derived from EUSES. Chemosphere 58, 1169-1176 (2005)

[4] Ma, H.W., Hung, M.L., Chen, P.C.: A systemic health risk assessment for the chromium cycle in Taiwan. In: Environment International, pp. 1-13 (2006)

[5] Kochera, D.C., Greim, H.: An approach to comparative assessments of potential health risks from exposure to radionuclides and hazardous chemicals. Environment International 27, 663-671 (2002)

[6] Miyamoto, K.-i., Naito, W., Nakanishi, J.: Application of an ecosystem model for aquatic ecological risk assessment of chemicals for a Japanese lake. Water Research 36, 1-14 (2002)

[7] Chapman, P.M.: Ecological risk assessment (ERA) and hormesis. The Science of the Total Environment 288, 131-140 (2002)

[8] Fernández, E.C.M.D., Vega, M.M.: Ecological risk assessment of contaminated soils through direct toxicity assessment. Ecotoxicology and Environmental Safety 62, 174-184 (2005) 